\title{
Profil Rujukan Kasus Nonspesialistik pada Fasilitas Kesehatan Tingkat Primer
}

\section{Referral Profile of Non-Specialistic Cases on Primary Healthcare Facilities}

\author{
Elda Nazriati ${ }^{*}$, Nuzelly Husnedi**
}

\author{
*Departemen Pendidikan Kedokteran Fakultas Kedokteran Universitas Riau, **Ikatan Dokter Indonesia Wilayah \\ Riau
}

\begin{abstract}
Abstrak
Salah satu indikator kualitas fasilitas kesehatan tingkat primer (FKTP) adalah rendahnya rujukan nonspesialistik. Rujukan nonspesialistik adalah rujukan dari 144 penyakit yang seharusnya dapat diatur di FKTP. Kenyataannya, masih banyak kasus nonspesialistik yang dirujuk ke fasilitas kesehatan sekunder. Penelitian deskriptif dengan metode campuran kuantitatif dan kualitatif ini bertujuan untuk mengetahui pola dan penyebab kasus penyakit nonspesialistik yang dirujuk ke fasilitas kesehatan tingkat sekunder di Kota Pekanbaru. Gambaran kasus penyakit nonspesialistik dikumpulkan dari data Badan Penyelenggara Jaminan Sosial Kesehatan Kota Pekanbaru periode Desember 2014 - April 2015, sedangkan faktor penyebab rujukan diperoleh dari focus group discussion yang diikuti oleh 40 dokter berdasarkan jenis FKTP. Penelitian ini menampilkan 20 kasus nonspesialistik yang paling sering dirujuk, di antaranya hipertensi esensial, miopia ringan, dan diabetes melitus. Penyebab rujukan kasus penyakit nonspesialistik antara lain kesalahan kode serta terbatasnya fasilitas, sumber daya manusia, manajemen pelayanan, dan kompetensi dokter. Semua faktor keterbatasan tersebut perlu diantisipasi agar upaya rujukan dapat diminimalkan.
\end{abstract}

Kata kunci: Fasilitas kesehatan tingkat primer, fasilitas kesehatan tingkat sekunder, rujukan nonspesialistik

\footnotetext{
Abstract

One of primary healthcare facility quality indicators is the low non-specialistic referral. Non-specialistic referral is referral of 144 diseases that should be arranged in primary healthcare facilities. In fact, there are many non-specialist cases referred to secondary health care facilities. This descriptive study using quantitative and qualitative method aimed to determine patterns and causes of non-specialist diseases referred to secondary primary health care in Pekanbaru City. Depiction of non-specialistic disease cases was collected from data of the state health insurance scheme in Pekanbaru City on December 2014 - April 2015 period, meanwhile causes of referral
}

were obtained from focus group discussion participated by 40 doctors based on types of primary healthcare facilities. This study showed 20 non-specialistic cases oftenly referred including essential hypertension, mild myopia and diabetes mellitus. Causes of non-specialistic disease referrals were code error as well as limited facilities, human resources, service management and competence of doctors. Such limitations need to be anticipated in order to minimalize act of referrals.

Keywords: Primary healthcare facilities, secondary healthcare facilities, non-specialistic referral

\section{Pendahuluan}

Dokter praktik umum di fasilitas kesehatan tingkat pertama (FKTP) merupakan pintu gerbang pelayanan kesehatan yang dituntut kompetensinya untuk menapis dan mengatur penyakit nonspesialistik secara lengkap. Rujukan pada layanan primer merupakan isu yang penting karena tingginya angka rujukan sering dihubungkan dengan inefisiensi, buruknya layanan, dan kegagalan diagnosis. Tingginya angka rujukan juga berdampak langsung pada pembiayaan kesehatan. ${ }^{1}$

Angka rujukan dari fasilitas kesehatan primer mengalami peningkatan dari tahun ke tahun. Penelitian di Amerika menunjukkan pada periode 1999 - 2009 terjadi peningkatan kasus rujukan hampir dua kali lipat, yaitu dari 4,8\% menjadi 9,3\%.2 Pada kenyatannya, banyak faktor yang memengaruhi tingginya angka rujukan, antara lain model layanan kesehatan, pengkodean diagnosis, karakteristik pasien, dan fasilitas kesehatan. ${ }^{1,3}$

Korespondensi: Elda Nazriati, Departemen Pendidikan Kedokteran Fakultas Kedokteran Universitas Riau, Jl. Diponegoro No. 1 Pekanbaru Riau, No.Telp: (0761) 839264,e-mail: eldanazriati@gmail.com 


\section{laksananya penelitian ini.}

\section{Daftar Pustaka}

1. British Medical Association Health Policy and Economic Research Unit; British Medical Association. Factors capable of influencing an increase in GP referral rates to secondary care (England only). London: British Medical Association; 2009.

2. Barnet MI, Song Z, London BE. Trends in physician referrals in United States, 1999-2009. Archives of Internal Medicine. 2012; 172 (2): 163 70 .

3. Liddy C, Singh J, Kelly R, Dahrouge S, Taljaard M, Younger J. What is the impact of primary care model type on specialist referral rates? A cross-sectional study. BMC Family Practice. 2014; 15: 22.

4. Frank P, Williams G.C, Zwanziger J, Mooney C, Sarbero M. Why do physicians vary so widely in their referral rates? Journal of General Internal Medicine. 2000;15; 163- 4.

5. Malik AH. Analisis peran dokter layanan primer sebagai gatekeeper di era jaminan kesehatan nasional (monitoring 3 bulan pertama pelayanan di PPK1 BPJS Kesehatan). Buku Prosiding Kongres InaHEA II, Jakarta, 7-10 April 2015 [Diakses pada 6 Oktober 2015]. Diunduh dalam: http://inahea.org/files/hari1/2.\%20Abd\%20Halik\%20Malik.pdf.

6. Idris F. Optimalisasi sistem pelayanan kesehatan berjenjang pada program Kartu Jakarta Sehat. Kesmas: Jurnal Kesehatan Masyarakat Nasional. 2014; 9 (1): 94-100.

7. Konsil Kedokteran Indonesia. Standar kompetensi dokter Indonesia. Edisi ke-2. Jakarta: Konsil Kedokteran Indonesia; 2012.

8. Pengurus Besar Ikatan Dokter Indonesia. Panduan praktik klinis dokter bagi dokter di fasilitas kesehatan primer. Edisi ke-1. Jakarta: Ikatan Dokter Indonesia; 2013

9. Bungin HMB. Penelitian kualitatif: Komunikasi, ekonomi, kebijakan publik, dan ilmu sosial lainnya. Edisi I cetakan ke 2. Jakarta: Kencana; 2008.

10. Direksi Badan Penyelenggara Jaminan Sosial Kesehatan. Surat keputusan direksi BPJS Kesehatan nomor 411 tahun 2014 tentang ujicoba sis- tem pembayaran kapitasi berbasis kinerja. Jakarta: BPJS Kesehatan; 2014.

11. Jabeen M. Impact of performance appraisal on employees motivation. European Jurnal of Business and Management. 2011; 3 (4): 197-204

12. Forrest CB, Nutting PA, Schrader, Rohde C, Starfield B. Primary care physician specialty referral decision making: patient, physician, and health care system determinants. Medical Decision Making. 2006; 26 (1): 67-85

13. Suyono S. Diabetes mellitus di Indonesia. Dalam Sudoyo AW, Setiyohadi B, Alwi I, Simadibrata M, Setiati S, eds. Buku ajar ilmu penyakit dalam. Edisi Keenam. Jakarta: Interna Publishing; 2014.p. 2315-22

14. Chant BT, Austin PC. Patient, physician, and community factors affecting referrals to specialists in Ontario, Canada: a population-based, multi-level modeling approach. Medical Care. 2003 Apr; 41: 500-11.

15. Badan Penyelenggara Jaminan Sosial Kesehatan Kesehatan. Panduan praktik pelayanan alat kesehatan. 2014 [Diakses pada tanggal 8 Desember 2015]. Diunduh dalam: http://bpjs-kesehatan.go.id/bpjs/dmdocuments/4b16c5b267e8d3651fdfb9880c6921f4.pdf

16. Blank L, Baxter S, Woods HB, Goyder E, Lee A, Payne N, Rimmer M. Referral interventions from primary to specialist care: a systematic review of international evidence. British Journal of General Practice. 2014; 64 (629): e765-74.

17. Evans E, Aiking H, Edwards A. Reducing variation in general practitioner referral rates through clinical engagement and peer review of referrals: a service improvement project. Quality in Primary Care. 2011; 19 (4): 263-72.

18. Vahidi RG, Mojahed F, Jafarabadi MA, Gholipour K, Rasi V. A Systematic review of the effect of payment mechanism on family physicians service provision and referral rate behavior. Journal of Pakistan Medical Student. 2013; 3 (1): 54-60

19. Kushnir T, Greenberg D, Madjar N, Hadari I, Yermiahu Y, Bachner YG. Is burnout associated with referral rates among primary care physicians in community clinics? Family Practice. 2014; 31 (1): 44-50. 